\title{
Human Immunodeficiency Virus and Immunological Profiles among Suspected Tuberculosis Cases in Mombasa County, Kenya
}

\author{
Shadrack A. Yonge ${ }^{1,2}$, Michael F. Otieno ${ }^{3}$, Rekha R. Sharma4, Sarah S. Nteka ${ }^{5}$ \\ ${ }^{1}$ Department of Environment and Health Sciences, Technical University of Mombasa, Mombasa, Kenya \\ ${ }^{2}$ Department of Community Health, Kenyatta University, Kahawa, Kenya \\ ${ }^{3}$ Department of Medical Laboratory Sciences, Kenyatta University, Kahawa, Kenya \\ ${ }^{4}$ Department of Zoological Sciences, Kenyatta University, Kahawa, Kenya \\ ${ }^{5}$ Department of Medical Laboratory, Coast General Referral Hospital, Mombasa, Kenya \\ Email: "shadrackyongez@yahoo.co.uk
}

Received 29 January 2016; accepted 19 March 2016; published 22 March 2016

Copyright (C) 2016 by authors and Scientific Research Publishing Inc.

This work is licensed under the Creative Commons Attribution International License (CC BY).

http://creativecommons.org/licenses/by/4.0/

(c) (i) Open Access

\section{Abstract}

Background: Human immunodeficiency virus (HIV) is a major public health concern and cause of death globally including Kenya. HIV infection is characterised by CD4+ lymphocyte depletion manifested through the loss of the immune response capacity. Aim: This study aimed to determine the prevalence of HIV infection and CD4+T cell counts among suspected tuberculosis (TB) cases seeking healthcare at TB clinics in Mombasa County, Kenya. Study Design: Hospital and laboratory based cross-sectional study was carried between May 2011 and November 2013 in Coast General Referral Hospital, Tudor, Port-Reitz, Mlaleo, Likoni and Mikandani districts and sub-districts hospitals. Methodology: A total of 500 suspected TB cases (271 males and 229 females) were screened for HIV infection using Trinity Biotech Uni-Gold ${ }^{\mathrm{TM}}$ test and positives confirmed with the enzymelinked immunosorbent assay. CD4+ and CD8+T cells were analyzed using a BD FACS Count flow cytometer. A questionnaire was used to collect demographic data of the participants. Results: In total, $127(25.4 \%)$ of the suspects were HIV infected $55.1 \%$ females and $44.9 \%$ males. Females were significantly affected than males $(\mathrm{OR}=0.78 ; 95 \% \mathrm{CI}$ : $0.44-1.37 ; \mathrm{p}=0.042)$. The majority (36.2\%) of the HIV cases were in the 25 - 34 years age group followed by the 35 - 44 (33.9\%), 45 $54(16.5 \%)$ and $18-24(7.1 \%)$ age groups, respectively. Widowed (AOR $=6.14 ; 95 \%$ CI: $1.53-$ 20.54; $\mathrm{p}<0.033)$, alcohol $(\mathrm{AOR}=2.83 ; 95 \% \mathrm{CI}: 1.71$ - 4.87; $\mathrm{p}<0.001)$ and condom use $(\mathrm{AOR}=2.31$; 95\% CI: $1.62=4.71 ; p<0.002$ ) were risk factors associated with HIV infection. The mean CD4 cell

\footnotetext{
"Corresponding author.
}

How to cite this paper: Yonge, S.A., Otieno, M.F., Sharma, R.R. and Nteka, S.S. (2016) Human Immunodeficiency Virus and Immunological Profiles among Suspected Tuberculosis Cases in Mombasa County, Kenya. Journal of Tuberculosis Research, 4, 34-45. http://dx.doi.org/10.4236/itr.2016.41005 
count was $333.27 \pm 150.59$ cells $/ \mathrm{mm}^{3}$ and it was higher in males $\left(343.05 \pm 149.33 \mathrm{cells} / \mathrm{mm}^{3}\right)$ than females $\left(325.93 \pm 152.92\right.$ cells). The mean values of white blood cells $\left.(5.9 \pm 2.42) \times 10^{9} / 1\right)$, packed cell value $(34.1 \% \pm 4.3 \%)$, platelets $(195.16 \pm 88.7) \times 10^{9} / 1$ and erythrocyte sedimentation rate $(102.0 \pm 17.4 \mathrm{~mm} / \mathrm{hr})$ were significantly lower than the control group $(\mathrm{p}<0.05)$. Conclusion: The prevalence of HIV infection among suspected TB cases was $25.4 \%$ which was higher than the current national average HIV prevalence of $6.9 \%$. Lower CD4+ lymphocyte count was found to be the only predicting factor for HIV. There was a significant relationship between CD4/ESR and HIV infection.

\section{Keywords}

HIV Prevalence, Healthcare Seekers, Suspected TB Cases, Immunohaematological Variables

\section{Introduction}

Human immunodeficiency virus (HIV) is a major public health problem and it causes death in many parts of Africa [1] [2]. Although the continent is home to about 15.2 percent of the world's population, Sub-Saharan Africa alone accounted for an estimated 69 percent of all people living with HIV and 70 percent of all AIDS deaths in 2013 [3]. The HIV spreads silently and unnoticed before it wreaks havoc and devastation [4]. It kills people, destabilizes communities, slows economies, disrupts social services and weakens democracies [5]. There were approximately 40 million people living HIV/AIDS in 2013; 33.2 million were adults of which $60 \%$ were women [3] [5]. An estimated 2.4 million people were newly infected with HIV in sub-Saharan Africa in 2013, bringing to 27.4 million the number of people living HIV in this region. By 2013, more than 18 million children in Sub-Saharan Africa had lost one or both parents to HIV/AIDS [6]. About 1.9 million people in Kenya are living with HIV/AIDS and Kenya is ranked fourth highest number of AIDS infections in the world [7]. There are at least 100,000 new HIV infections in Kenya annually. The epidemic is spreading fast in rural areas with less health facilities compared with the urban areas. The spread in rural area is accelerated by poverty, ignorance and lack of information about proper methods of prevention [8]. As evident, the number of HIV new infections keeps on soaring, a clear indicator that people are not doing enough to contain the spread of the virus [9]. The national prevalence rate is currently $6.9 \%$ and is the highest among the married couples and young women who are more vulnerable to infection [10]. The number of adults in need of ART reached 213,000 in 2005 and is estimated to have reached 930,000 in 2013 based on CD4 < 350. During the same period, the ART needs among children ( 0 - 14) rose from 103,000 to 205,000 [11]. It is widely known that behavioural factors like traditional attitudes, multiple sexual partners, pre-marital sexual activity and drug abuse (intravenous drug users) significantly contribute to increased HIV infection in this region. 17\% of new HIV infections at coastal Kenya are linked to intravenous drug use [12].

Immuno-haematological indices such as leukocyte, lymphocytes and their subsets such as CD4+T cells and CD8+T cells play a major role in both cellular and humoral types of immunity. CD4+T cells are the lymphocytes subsets used for monitoring progression of HIV/AIDS infection and they are also used as a surrogate marker for the improvement of HIV/AIDS patients after initiation of ARV [13]. Further, CD4+T cell levels determine when to start or stop prophylactic drugs for opportunistic infections [14]. Management of HIV patients includes proper monitoring, irrespective of ARV treatment. This monitoring can be done clinically by means of the WHO clinical staging, but more reliably by measuring CD4+T cells and viral load [3]. In resource poor countries like Kenya, viral load determination is not done and the only reliable methods for follow up of HIV infected patients are by CD4+T cell counts [15]. Immuno-haematological variations have been reported in various studies showing association with sex, geographical location, race, altitude and diet [16]. The HIV virus targets and destroys CD4+T cells responsible for the cellular immunity against infections by intracellular microorganisms like M. tuberculosis. Reduction in CD4+T cells results in immunodeficiency which in turn can lead to reactivation of latent tuberculosis or new tuberculosis infection once exposed to M. tuberculosis [17]-[20]. A normal CD4 count in a healthy, HIV negative adult can vary but is usually between 500 and 1700 CD4 cells $/ \mathrm{mm}^{3}$ though it can be lower in some people. The principal impact of HIV infection in the immune system is destruction of the CD4+T-lymphocytes during which primary infection, HIV and HIV-infected cells reach the 
lymph nodes and other lymphoid tissues [21]. The virus rapidly disseminates during this early stage of HIV infection leading to significant fall in CD4 cells and high viral levels. The present study aimed at identifying the prevalence of HIV and CD4 count among newly diagnosed TB patients in Mombasa County in Kenya.

\section{Materials and Methods}

\subsection{Study Area}

The study was conducted in Mombasa County which has a population of 1,031,266 by the year 2012. The population is steadily growing due to rural-urban migration and immigration from unstable countries. The total area Mombasa is $109 \mathrm{Km}^{2}$ with about $60 \%$ of the people living overcrowded informal settlements in the form of shelters. Residents are of mixed ethnicity and are engaged in low-income generating activities, mainly informal sector and small trading. The County has rapid population growth and is characterized by low socio-economic indicator. This creates huge demands on health facilities and inability to keep pace with the environment, continued economic prosperity, public health and quality of life of residents. Tuberculosis and HIVAIDS are the leading causes of deaths in the area representing $50 \%$.

\subsection{Study Site}

The study was done at done at Ganjoni clinic, Coast provincial General hospital (CPGH), Mlaleo Health and Mikindani Health centers, Likoni, Portreizt and Tudor district hospitals. These hospitals were selected because they serve populations at high risk for TB due to high HIV prevalence or social-cultural practices that favour TB transmission. These hospitals like all others at their levels have chest clinics where TB patients obtain health care respectively.

\subsection{Study Design}

This was hospital and laboratory based descriptive cross-sectional study carried out between May 2011 to November 2013. The study sites facilitated the recruitment of 500 study participants into the study from suspected TB cases. The minimum sample size was determined using Fischer’s formula.

\section{Inclusion and Exclusion Criteria}

Those suspected of having TB and residents in Mombasa County for at least six (6) months, not on anti-TB chemotherapy and consented to participate in the study were recruited. Tuberculosis suspects who had not lived in Mombasa County for the last six (6 months), unwilling to participate in the study and not meeting the above inclusion criteria were excluded.

\subsection{Sampling Frame}

Mombasa County was purposively sampled because of high cases of TB and HIV infection. The sampling frame consisted of all the public health facilities within the study area. After the selection of the study sites, each was allocated a proportionate number of study subjects based on the level of health care delivery system and the average client attendance in the past one month before embarking on the study. To minimize bias in selecting study subjects, consecutive sampling was used hence every alternate TB suspect who satisfied the inclusion criteria were selected for the study during the intake period.

\subsection{Collection of Demographic Data}

A structured and pre-tested questionnaire was used to obtain participant demographic data. The data collected included age, gender, previous anti-TB treatment, HIV status and antiretroviral therapy (ART).

\subsubsection{Collection of Blood Samples}

A total of 500 participants consented phlebotomy for HIV testing. Testing was also done according to manufacturer's instructions. Blood samples were delivered in vacutainer Brand STERILE interior ethylene diaminetetra-acetic acid (EDTA) tubes and used for HIV test, complete blood cell (CBC) counts and for CD4+T cell counts. The safety for research assistants and healthcare workers during collection and handling of blood speci- 
mens was ensured by observing the WHO guideline.

\subsubsection{HIV Testing}

Blood samples were tested for HIV antibodies according to the Kenyan national testing algorithm for voluntary counseling and testing. Testing for HIV infection was done by screening serum/plasma by using Determine HIV1/2 (Abott laboratories, Japan co. LTD), Capillus HIV1/2 (The Trinity Biotech, Ireland) and Unigold H1/2 [22] rapid test kits and positives confirmed with the enzyme linked immunosorbent assay [23].

\subsubsection{CD4+T and CD8+T Cell Determination}

The puncture area was identified, swabbed with alcohol and blood sample collected by a well-trained phlebotomist. Blood samples were collected by venipuncture using a $10 \mathrm{ml}$ syringe and $21 \mathrm{~g}$ needle which were all sterile. Whole blood samples were collected in $4.5 \mathrm{ml}$ BD K2E vacutainer (lavender cap) and mixed adequately with the EDTA by gently inverting up and down for at least ten times to avoid clotting. Blood was processed within 24 hrs after collection. The test vial was vortexed upside down and then upright for 5 seconds each to ensure even mixing. Fifty microliter (50 ul) of blood was added to the vial using the back pipetting technique with an electronic pipette and vortexed again for 5 seconds before incubating in the dark for a period of 1 hour at room temperature. At the end of the incubation period, the product was fixed with a $50 \mu$ l fixative solution and vortexed to ensure even mixing. The reagent tubes were placed onto the holder beneath the probe and allowed the machine to read the CD4+ sample.

\subsubsection{Haematological Assay}

Haematological parameters: haemoglobin (Hb), haematocrit (PCV), white blood cell count (WBC), platelet count (PLT) were determined using the automated blood analyzer cell-Dyn 1800 (Abbot Laboratories Diagnostics Division, USA).

\subsubsection{Screening for Malnutrition}

All participants were screen were assessed for malnutrition using body mass index (BMI). Normal nutrition status was defined as BMI $>18.5 \mathrm{~kg} / \mathrm{m}^{2}$, mild malnutrition as BMI of $17.5-18.4 \mathrm{~kg} / \mathrm{m}^{2}$, moderate malnutrition as BMI of $16-17.4 \mathrm{~kg} / \mathrm{m}^{2}$ and severe malnutrition as BMI $<16 \mathrm{~kg} / \mathrm{m}^{2}$.

\subsubsection{Data Management and Analysis}

Demographic data were confidentially obtained from the TB suspects by clinicians/nurses running the chest clinics. Data was recorded on questionnaires, register books, ELISA reader print-outs and species evaluation sheets. The data was coded, entered into MS Excel 8.0 and processed using a statistical package for social sciences (SPSS) version 16.5 software for windows. The chi-squared $\left(\chi^{2}\right)$ test was used to compare categorical data and logistics regression to analyze multivariate data. Univariate odds ratio (OR) and $95 \%$ interval (CI) were calculated to assess risk factors (gender and age-group) with regard to HIV infection. Logistic regression was used to analyze multivariate data. The strength of an association. $p$ values of $<0.05$ were considered statistically significant.

\subsubsection{Ethical Issues}

The proposal for this study was approved by Kenyatta University Ethical Review Committee (No PKU018/115). It was approved by the ministry of education, Science and Technology (MOEST). Clearance was also obtained from respective district health authorities and hospital administrations. The purpose of the study was explained participants in English, Kiswahili or local language before consent was sought. The study was conducted in accordance with the declaration of Helsinki. Code numbers rather than names were used to identify candidates in order to maintain confidentiality. The study did not expose candidates to any unusual risks as competent hospital staff obtained sputum and blood specimens from candidates using standard procedures.

\section{Results}

\subsection{Socio-Demographic Characteristics of the TB Suspects}

A total of 500 participants suspected of having TB were enrolled in this study of which 271 (54.2\%) were males 
and 229 (45.8\%) females. Their ages were between 18 and 80 years and median age being 32 years. The majority (42.4\%) of the participants were in the 25 - 34 years age-group, followed by those in the 35 - 44 (24.4\%), 18 - 24 (19.2\%) 45 - 54 (9.8) and 55+ (3.4\%) age groups respectively. Four hundred and twenty five (85\%) had attained secondary and college levels of education while 73 (14.6\%) primary level. Two hundred and eighty one (56.2\%) of the participants were married, 192 (38.4\%) unmarried and 21 (4.2\%) widowed (Table 1).

\subsection{HIV Prevalence Rate}

A total of five hundred TB suspects who participated in this study accepted to undergo HIV testing and $25.4 \%$ (127/500) were sero-positive. Females constituted 45.8\% (229/500) of which 30.6\% (70/229) being sero-positive. Males constituted 54.2\% (271/500), with 18.5\% (50/271) being infected. Overall females constituted 55.1\% and males $44.9 \%$ of the HIV cases. There was significant difference in HIV infection rate between gender with females being more vulnerable than men (OR = 0.783; 95\% CI: $0.447-1.372 ; \mathrm{p}=0.042)$. The majority (36.2\%) of the HIV cases were in the 25 - 34 years age group followed by age groups 35 - 44 (33.9\%), 45 - 54 (16.5\%) and 18 - 24 (7.1\%) respectively (Table 2). In marital status, 27\% of married were sero-positive and 40\% in singles. Risk factors associated with undiagnosed HIV in men were widowed (AOR = 6.14; 95\% CI; 1.53 - 20.54 ; $\mathrm{p}<0.033$ ), alcohol (AOR = 2.83; 95\% CI: 1.71 - 4.87; $<$ < 0.001) and condom use (AOR = 2.31; 95\% CI: 1.62 $=4.71 ; \mathrm{p}<0.002)$. Among undiagnosed HIV in women were aged 25 - 44 years $(\mathrm{AOR}=2.43$; $95 \% \mathrm{CI} ; 1.21$ 10.32; $\mathrm{p}<0.041$ ), being divorced (AOR $=2.41$; 95\% CI: 1.32 - 4.02; $<<0.05$ ) and reporting three or more lifetime sexual partners $(\mathrm{AOR}=1.70 ; 95 \% \mathrm{CI}, 1.21-4.10: \mathrm{p}<0.024)$. History of STI was also risk in both cases

Table 1. Socio-demographic characteristics of the TB suspects $(n=500)$.

\begin{tabular}{|c|c|c|c|c|}
\hline Characteristic & Groupings & Female $(\mathrm{n}=229)$ & Male $(n=271)$ & Total $(\mathrm{n}=500)$ \\
\hline \multirow{6}{*}{ Age in years } & $18-24$ & 44 (19.2\%) & $52(19.2 \%)$ & $96(19.2 \%)$ \\
\hline & $25-34$ & $101(44.1 \%)$ & 115 (42.4\%) & 216 (43.2\%) \\
\hline & $35-44$ & $53(23.1 \%)$ & 69 (25.5\%) & 122 (24.4\%) \\
\hline & $45-54$ & $21(9.2 \%)$ & $28(10.3 \%)$ & $49(9.8 \%)$ \\
\hline & $55^{+}$ & $10(4.4 \%)$ & $7(2.6 \%)$ & 17 (3.4\%) \\
\hline & Mean age & $32.84 \pm 9.90$ & $32.75 \pm 9.64$ & $32.79 \pm 9.75$ \\
\hline \multirow{4}{*}{ Education level } & College & 77 (33.6\%) & 82 (30.3\%) & 159 (31.8\%) \\
\hline & No education & $1(0.4 \%)$ & $1(0.4 \%)$ & $2(0.4 \%)$ \\
\hline & Primary & $39(17.0 \%)$ & $34(12.6 \%)$ & $73(14.6 \%)$ \\
\hline & Secondary & 112 (48.9\%) & 154 (56.8\%) & 266 (53.2\%) \\
\hline \multirow{4}{*}{ Marital status } & Divorced & 2 (0.9\%) & $4(1.5 \%)$ & $6(1.2 \%)$ \\
\hline & Married & $122(53.3 \%)$ & 159 (58.7\%) & $281(56.2 \%)$ \\
\hline & Unmarried & 89 (38.9\%) & $103(38.0 \%)$ & 192 (38.4\%) \\
\hline & Widowed & $16(7.0 \%)$ & $5(1.9 \%)$ & $21(4.2 \%)$ \\
\hline \multirow{7}{*}{ Employer } & Government & 55 (24.0\%) & 66 (24.4\%) & 121 (24.2\%) \\
\hline & Jobless & 59 (25.8\%) & 66 (24.4\%) & 125 (25.0\%) \\
\hline & House wife & $6(2.6 \%)$ & 27 (10.0\%) & 33 (6.6\%) \\
\hline & Others ${ }^{*}$ & $13(5.7 \%)$ & $34(12.6 \%)$ & $47(9.4 \%)$ \\
\hline & Farmer & $15(6.6 \%)$ & $9(3.3 \%)$ & $24(4.8 \%)$ \\
\hline & Self employed & 79 (34.5\%) & 67 (24.7\%) & $146(29.2 \%)$ \\
\hline & Student & $2(0.9 \%)$ & $2(0.7 \%)$ & $4(0.8 \%)$ \\
\hline
\end{tabular}

*Other occupations include daily labourers, commercial sex workers and house hold servants. 
Table 2. HIV prevalence and gender-age distribution $(\mathrm{n}=127)$.

\begin{tabular}{ccccccc}
\hline Age-group & $\mathrm{N}(\%)$ & Males (\%) & Females (\%) & OR & $95 \%$ CI & p-value \\
\hline $18-24$ & $9(7.1 \%)$ & $4(7.0 \%)$ & $5(7.1 \%)$ & 0.415 & $0.031-1.421$ & 0.311 \\
$25-34$ & $46(36.2 \%)$ & $21(36.8 \%)$ & $25(35.7 \%)$ & 0.820 & $0.412-1.632$ & 0.571 \\
$35-44$ & $43(33.9 \%)$ & $18(31.6 \%)$ & $25(35.7)$ & 0.543 & $0.286-1.033$ & 0.063 \\
$45-54$ & $21(16.5 \%)$ & $11(19.3 \%)$ & $10(14.3 \%)$ & 0.479 & $0.188-1.218$ & 0.052 \\
$55+$ & $8(6.3 \%)$ & $3(5.3 \%)$ & $5(7.1)$ & 1.030 & $0.359-2.953$ & 0.356 \\
Total & $\mathbf{1 2 7 ( 1 0 0 )}$ & $\mathbf{5 7}(\mathbf{4 4 . 9 \% )}$ & $\mathbf{7 0 ~ ( 5 5 . 1 \% )}$ & $\mathbf{0 . 7 8 3}$ & $\mathbf{0 . 4 4 7 - 1 . 3 7 2}$ & $\mathbf{0 . 0 4 2}$ \\
\hline
\end{tabular}

$(\mathrm{AOR}=2.41 ; 95 \% \mathrm{CI}, 1.61$ - 3.67; $\mathrm{p}<0.0001)$. Only 27\% (35/127) of the HIV/AIDS cases were on antiretroviral therapy (ART), 66.7\% females and 33.7\% males.

\subsection{Immunological Status of Human Immunodeficiency Virus (HIV)}

Table 3 shows the mean and standard distribution of measured immunological parameters. From the seventy eight (78) HIV+ sampled population, the mean absolute CD4+T count in males and females combined was $333.27 \pm 150.59$ cells $/ \mathrm{mm}^{3}$. Mean in males was $343.05 \pm 149.33$ cells $/ \mathrm{mm}^{3}$ and females $325.93 \pm 152.92$ cells $/ \mathrm{mm}^{3}$. The mean CD4+T cells count in males was lower than for females but the difference was not statistically significant $(\mathrm{t}=0.754$, $\mathrm{df}=76, \mathrm{p}>0.05)$. The calculated combined CD8+T lymphocyte counts was 750.59 \pm 289.93 cells $/ \mathrm{mm}^{3}$ and it was higher in females $756.89 \pm 318.27$ cells than males $742.19 \pm 254.69$ cells $/ \mathrm{mm}^{3}$ but there was however no statistical significance $(\mathrm{t}=0.174, \mathrm{df}=47, \mathrm{p}>0.863)$. The mean CD4+/CD8+ ratio in males and females combined was $0.487 \pm 0.265$ cells $/ \mathrm{mm}^{3}$, with mean in males being $0.51 \pm 0.279$ cells $/ \mathrm{mm}^{3}$ and females $0.47 \pm 0.258$ cells $/ \mathrm{mm}^{3}$. The mean total CD3+T lymphocyte counts was $1189.55 \pm 348.44$ cells $/ \mathrm{mm}^{3}$ with males showing lower value $\left(1157.67 \pm 370.57\right.$ cells $\left./ \mathrm{mm}^{3}\right)$ than females $(1213.46 \pm 335.76$ cells $/ \mathrm{mm}^{3}$ ). The mean haemoglobin levels in males and females combined was $11.28 \pm 1.49 \mathrm{gm} / \mathrm{dl}$. Females had lower haemoglobin mean levels $11.13 \pm 1.58 \mathrm{gm} / \mathrm{dl}$ than males $11.47 \pm 1.37 \mathrm{gm} / \mathrm{dl}$ which was statistically significant $(\mathrm{t}=1.23$, $\mathrm{df}=76, \mathrm{p}<0.042)$. On nutritional status assessment using BMI, the mean BMI for the participants was $19.91 \pm 2.16 \mathrm{~kg} / \mathrm{m}^{2}$. The mean BMI for males was $19.97 \pm 1.75 \mathrm{~kg} / \mathrm{m}^{2}$ and females $19.87 \pm 2.46$ $\mathrm{kg} / \mathrm{m}^{2}$. There was no statistically significant difference between males and females with regards to nutritional status $(\mathrm{t}=0.157$, $\mathrm{df}=47, \mathrm{p}<0.876)$.

\subsection{Mean CD4+, CD8+, BMI and HB in Different Study Groups}

Tuberculosis patients had statistically significant lower mean CD4+T counts $474.5 \pm 198.8$ cells $/ \mathrm{mm}^{3}$ than the reference value found in this population $\left(1054.9 \pm 156.1\right.$ cells $/ \mathrm{mm}^{3}, \mathrm{t}=34.6$, $\left.\mathrm{df}=485, \mathrm{p}=0.001\right)$ and lower haemoglobin level $(11.16 \pm 5.9 \mathrm{gm} / \mathrm{dl})$ than the reference value for this population $(12.8 \pm 13 \mathrm{~g} / \mathrm{dl}, \mathrm{t}=27.5$, $\mathrm{df}=$ 453, $\mathrm{p}=0.002)$. Tuberculosis patients had statistically significant higher CD4+T counts (474.5 \pm 198.8 cells $/ \mathrm{mm}^{3}$ ) than HIV/AIDS patients $(333.3 \pm 150.6, \mathrm{t}=4.6, \mathrm{df}=47, \mathrm{p}=0.001)$ and HIV/AIDS patients not on treatment $(290 \pm 184, \mathrm{t}=7.6, \mathrm{df}=58, \mathrm{p}=0.05)$. Tuberculosis patients had significant lower mean haemoglobin level $(11.2 \pm 5.9 \mathrm{gm} / \mathrm{dl})$ than HIV/AIDS patients $(11.3 \pm 1.5, \mathrm{t}=3.4$, $\mathrm{df}=47, \mathrm{p}=0.001)$. Patients with tuberculosis were significantly malnourished (BMI $19.7 \pm 2.4 \mathrm{~kg} / \mathrm{m}^{2}$ ) as compared to the reference value for this population (BMI $22.7 \pm 1.3, \mathrm{t}=8$, $\mathrm{df}=465, \mathrm{p}<0.05)$. HIV/AIDS patients had significantly higher BMI $(19.9 \pm 2.2$ $\mathrm{kg} / \mathrm{m}^{2}$ ) than tuberculosis HIV/AIDS co-infected patients (BMI $\left.16.9 \pm 2.2, \mathrm{t}=0.70, \mathrm{df}=58, \mathrm{p}<0.021\right)$ and lower compared to values obtained for control subjects ( $\mathrm{p}<0.003$ ) (Table 4).

\subsection{Baseline Data of Immunological Markers}

Table 5 shows the means and standard deviations of the haematological variables. 127 (25.4\%) were HIV sero-positive, 78 (37.1\%) HIV and TB co-infected, 210 (42.0\%) newly diagnosed TB patients respectively. The mean findings from the total leucocyte (WBC) blood cell count showed HIV+TB- had $(5.9 \pm 2.42) \times 10^{9} / \mathrm{l}$, 
Table 3. Mean CD4+T cells, CD8+T cells, CD4/CD8 ratio, haemoglobin and BMI cells in HIV ( $\mathrm{n}=127)$.

\begin{tabular}{|c|c|c|c|c|c|}
\hline Gender & $\mathrm{N}$ & Median & Mean \pm std. dev. & $95 \%$ CI & p-value \\
\hline \multicolumn{6}{|c|}{ Absolute CD4 T cells } \\
\hline Male & 57 & 339 & $343.05 \pm 149.33$ & $275.07-411.02$ & \multirow{3}{*}{$\begin{array}{c}\mathrm{t}=0.392 \\
\mathrm{df}=47 \\
\mathrm{p}=0.697\end{array}$} \\
\hline Female & 70 & 325 & $325.93 \pm 152.92$ & $266.63-385.22$ & \\
\hline Total & 127 & 339 & $333.27 \pm 150.59$ & $290.16-376.37$ & \\
\hline \multicolumn{6}{|c|}{ Absolute CD8 T cells } \\
\hline Male & 57 & 695 & $742.19 \pm 254.69$ & $626.26-858.13$ & \multirow{3}{*}{$\begin{array}{c}\mathrm{t}=-0.174 \\
\mathrm{df}=47 \\
\mathrm{p}=0.863\end{array}$} \\
\hline Female & 70 & 715.5 & $756.89 \pm 318.27$ & $633.48-880.30$ & \\
\hline Total & 127 & 709 & $750.59 \pm 289.93$ & 667.31 - 833.87 & \\
\hline \multicolumn{6}{|c|}{ Absolute CD4/CD8 T cells } \\
\hline Male & 57 & 0.488 & $0.51 \pm 0.279$ & $0.383-0.637$ & \multirow{3}{*}{$\begin{array}{c}\mathrm{t}=0.655 \\
\mathrm{df}=47 \\
\mathrm{p}=0.604\end{array}$} \\
\hline Female & 70 & 0.481 & $0.47 \pm 0.258$ & $0.370-0.570$ & \\
\hline Total & 127 & 0.488 & $0.487 \pm 0.265$ & $0.411-0.563$ & \\
\hline \multicolumn{6}{|c|}{ Absolute CD3 T cells } \\
\hline Male & 57 & 1248 & $1157.67 \pm 370.57$ & $988.98-1326.35$ & \multirow{3}{*}{$\begin{array}{c}\mathrm{t}=-0.551 \\
\mathrm{df}=47 \\
\mathrm{p}=0.584\end{array}$} \\
\hline Female & 70 & 1225 & $1213.46 \pm 335.76$ & 1083.27 - 1343.66 & \\
\hline Total & 127 & 1240 & $1189.55 \pm 348.44$ & 1089.47 - 1289.64 & \\
\hline \multicolumn{6}{|c|}{ Haemoglobin cells } \\
\hline Male & 57 & 11.6 & $11.47 \pm 1.37$ & $10.843-12.091$ & \multirow{3}{*}{$\begin{array}{c}\mathrm{t}=0.776 \\
\mathrm{df}=47 \\
\mathrm{p}=0.042\end{array}$} \\
\hline Female & 70 & 11.05 & $11.13 \pm 1.58$ & $10.520-11.744$ & \\
\hline Total & 127 & 11.3 & $11.28 \pm 1.49$ & $10.848-11.703$ & \\
\hline \multicolumn{6}{|l|}{ BMI cells } \\
\hline Male & 57 & 19.6 & $19.97 \pm 1.75$ & $19.17-20.76$ & \multirow{3}{*}{$\begin{array}{c}\mathrm{t}=0.157 \\
\mathrm{df}=47 \\
\mathrm{p}=0.876\end{array}$} \\
\hline Female & 70 & 19.5 & $19.87 \pm 2.46$ & $18.91-20.82$ & \\
\hline Total & 127 & 19.5 & $19.91 \pm 2.16$ & $19.29-20.53$ & \\
\hline
\end{tabular}

CD4+ = cluster differentiation T-lymphocyte no.4; CD8+ = cluster differentiation T lymphocyte no.8; BMI = body mass index; $\mathrm{SD}=$ standard deviation; $\mathrm{CI}=$ confidence interval.

Table 4. Mean CD4+, CD8+, BMI and HB in different study groups.

\begin{tabular}{|c|c|c|c|c|}
\hline $\begin{array}{c}\text { Immuno-haematological } \\
\text { variables }\end{array}$ & $\begin{array}{l}\mathrm{HIV}+/ \mathrm{TB}+(\mathrm{N}=78) \\
(\text { mean } \pm \mathrm{SD})\end{array}$ & $\begin{array}{l}\mathrm{HIV}-/ \mathrm{TB}+(\mathrm{N}=210) \\
(\text { mean } \pm \mathrm{SD})\end{array}$ & $\begin{array}{l}\mathrm{HIV}-/ \mathrm{TB}-(\mathrm{N}=500) \\
(\text { mean } \pm \mathrm{SD})\end{array}$ & p-value \\
\hline $\mathrm{CD} 4+\mathrm{T}$ cells $/ \mathrm{mm}^{3}$ & $265.1 \pm 158.4$ & $474.5 \pm 198.8$ & $1054.9 \pm 156.1$ & 0.001 \\
\hline $\mathrm{CD} 8+\mathrm{T}$ cells $/ \mathrm{mm}^{3}$ & $796.5 \pm 265.7$ & $614.8 \pm 247.5$ & $679.1 \pm 697.7$ & 0.000 \\
\hline $\mathrm{CD} 3+\mathrm{T}$ cells $/ \mathrm{mm}^{3}$ & $1165.2 \pm 343.3$ & $1271.0 \pm 350.7$ & $1907.4 \pm 1982.2$ & 0.000 \\
\hline $\mathrm{HB}$ gr/dl & $11.1 \pm 9.4$ & $11.2 \pm 5.9$ & $12.7 \pm 12.9$ & 0.002 \\
\hline $\mathrm{BMI} \mathrm{kg} / \mathrm{m}^{2}$ & $16.9 \pm 2.2$ & $19.7 \pm 2.4$ & $22.7 \pm 1.3$ & 0.000 \\
\hline
\end{tabular}

CD4+ = cluster differentiation T-lymphocyte no.4; CD8+ = cluster differentiation T-lymphocyte no.8; MI = body mass index; SD = standard deviation; $\mathrm{p}$-value = level of marginal significance; Yates corrected chi-square test for categorical variables. 
Table 5. Baseline data of immuno-haematological markers of the respondents.

\begin{tabular}{ccccccc}
\hline \multirow{2}{*}{ Immuno-haematological variables } & $\begin{array}{c}\text { HIV }+/ \mathrm{TB}- \\
(\mathrm{N}=127)\end{array}$ & $\begin{array}{c}\text { HIV }+/ \mathrm{TB}+ \\
(\mathrm{N}=78)\end{array}$ & $\begin{array}{c}\text { HIV-/TB }+ \\
(\mathrm{N}=210)\end{array}$ & $\begin{array}{c}\text { HIV-/TB- } \\
(\mathrm{N}=500)\end{array}$ & p-value \\
\cline { 2 - 5 } & Mean $\pm \mathrm{SD}$ & Mean $\pm \mathrm{SD}$ & Mean $\pm \mathrm{SD}$ & Mean $\pm \mathrm{SD}$ & \\
\hline White blood cells $\left(\times 10^{9} / \mathrm{L}\right)$ & $5.9 \pm 2.3$ & $4.9 \pm 2.2$ & $5.3 \pm 2.2$ & $6.9 \pm 3.1$ & 0.00 \\
Packed cells volume $(\%)$ & $34.1 \pm 4.3$ & $32.3 \pm 4.8$ & $35.0 \pm 1.3$ & $36.9 \pm 4.2$ & 0.00 \\
Platelets count $\left(\times 10^{9} / \mathrm{L}\right)$ & $195.2 \pm 88.7$ & $163.3 \pm 65.1$ & $161.2 \pm 73.1$ & $240.1 \pm 99.4$ & 0.00 \\
Erythrocytes sedimentation rate $(\mathrm{mm} / \mathrm{hr})$ & $102.0 \pm 17.4$ & $115.1 \pm 11.8$ & $54.0 \pm 40.0$ & $10.0 \pm 8.5$ & 0.00 \\
\hline
\end{tabular}

$\mathrm{t}=7.45, \mathrm{df}=521, \mathrm{p}<0.05)$; SD = standard deviation; $\mathrm{p}$-value = level of marginal significance; Yates corrected chi-square test for categorical variables.

$\mathrm{HIV}+\mathrm{TB}+(4.9 \pm 2.2) \times 10^{9} / \mathrm{l}, \mathrm{HIV}-/ \mathrm{TB}+(4.9 \pm 2.2) \times 10^{9} / 1$ whilst the healthy control subjects reported $(6.92 \pm$ $3.12) \times 10^{9} /$. Mean packed cell volume $(\mathrm{PCV})$ among HIV+/TB- patients was $(34.1 \% \pm 4.3 \%), \mathrm{HIV}+/ \mathrm{TB}+$ $(32.3 \% \pm 4.8 \%), \mathrm{HIV}-/ \mathrm{TB}+(35.1 \% \pm 1.3 \%)$ and the control group $(36.3 \% \pm 4.2 \%)$. The mean platelets count from the study indicated HIV+/TB- had $(195.16 \pm 88.7) \times 10^{9} / \mathrm{l}, \mathrm{HIV}+/ \mathrm{TB}+(163.3 \pm 65.1) \times 10^{9} / \mathrm{l}, \mathrm{HIV}-/ \mathrm{TB}+$ $\left.(161.2 \pm 73.1) \times 10^{9} / \mathrm{l}\right)$ and the healthy control subjects $\left.(240.1 \pm 99.4) \times 10^{9} / \mathrm{l}\right)$. Meanwhile, the mean Erythrocyte sedimentation rate (ESR) from the study revealed that the findings for HIV+/TB- was $102.0 \pm 17.4 \mathrm{~mm} / \mathrm{hr}$, (HIV+/TB+ $115.1 \pm 11.8 \mathrm{~mm} / \mathrm{hr}), \mathrm{TB}+/ \mathrm{HIV}-(54.0 \pm 40.0 \mathrm{~mm} / \mathrm{hr})$ whilst HIV-/TB- (control) $10.0 \pm 8.5 \mathrm{~mm} / \mathrm{hr}$ (Table 5). The mean values obtained for immuno-haematological parameters of HIV+ patients were significantly lower $(\mathrm{p}<0.001)$ than values obtained for the control groups. There was a negative correlation $(r=$ 0.0341; $\mathrm{p}<0.005$ ) between packed cell volume and erythrocyte sedimentation rate.

\section{Discussion}

There is variable information concerning prevalence of HIV infected patients in the Kenyan population. The prevalence of HIV infection in this present study was $25.4 \%$ which was higher as compared to the national combined prevalence of 7.9\%. It was higher than the 8.5\% reported by Ngowi in Northern Tanzania [40]. However, the high overall HIV prevalence (25.4\%) in present study could be attributed to the study having been done among high risk groups. HIV is the greatest risk factor for the progression of latent TB infection to active TB and relapses [24] [25]. In our study, close to 70.1\% of the HIV infections were in the age 25 - 44 year age-group. This comprise the young and economically productive group in the community and constitutes human resources in terms of national productivity. This scenario was similar from the findings of a study done in rural Tanzania which revealed that older age groups are at higher risk of HIV infection compared to younger age group (14 - 24) [41]. The HIV prevalence rate is highest among married couples which has been fuelled by rampant infidelity in marriages popular known as "mpangowakando” in Kenya slang. The prevalence of HIV cases in females in this current study was $55.1 \%$ compared $44.9 \%$ in males. There was a significant difference in HIV infection rate between gender, females being more vulnerable compared to men (OR = 0.783; 95\% CI 0.447 - 1.372; $\mathrm{p}<0.05$ ). In the same period during the current study the NASCOP (2013) reported national HIV prevalence of $4.9 \%$ and $6.9 \%$ among males and females respectively which is in agreement in terms of females being more vulnerable. A study done in Sub-Saharan African indicated that HIV prevalence was 8.7\% in most general populations [25]. Biological, cultural and socio-economic factors contributes to women's greater vulnerability to HIV/AIDS. Women are four times more at risk of becoming affected with HIV during unprotected vaginal intercourse than men. The vagina's large surface area of susceptible tissue and micro trauma during intercourse makes women more physiologically vulnerable [26]. In this study, we found HIV-1 as the predominant viral subtype responsible for HIV infection in Mombasa, Kenya. The finding is consistent with studies in other parts of Africa which found HIV-1 is the predominant viral subtype [28]. Never the lees HIV-2 infection has been detected in other studies amongst African populations [29]. Socio-economic factors including women's lack of access to education or personal income perpetuate women's lower status. Moreover widespread poverty drives some women into commercial sex work. We also found that HIV prevalence was significantly higher among singles compared to married subjects. This finding is also consistent with previous reports which found single, unmarried persons more vulnerable to HIV infection [30]. Single unmarried persons are more likely to maintain multiple sex part- 
ners or be involved in high risk sexual behaviours like alcohol use and intravenous drug abuse that make them vulnerable to infection with HIV. A previous study done in the United States has shown that people who use alcohol, tobacco and other drugs are at a high risk for HIV infection. They are likely to engage in high-risk behaviours such as unprotected sex when they are under the influence of drugs or alcohol [31]. Research conducted throughout Sub-Saharan Africa has found close association between drug use, risk taking sexual behaviour and alcohol.

In this study the mean CD4+T lymphocyte count of the HIV infected was significantly lower $(\mathrm{p}=0.001)$ $\left(333.27 \pm 150.59\right.$ cells $\left./ \mathrm{mm}^{3}\right)$ compared to counts of non-infected $\left(1054.91 \pm 156.13 \mathrm{cells} / \mathrm{mm}^{3}\right)$. The findings of this study were consistent with the report of Tarbarsiet et al. [32] and the statistical analysis showed that more men were in the category of $>300$ CD4+T cell counts. It was also in agreement with previous reports in Nigeria and Ethiopia [33] [34]. HIV infects cells that have the CD4+T antigen molecules on their surface. In recent years, it has been discovered that HIV needs other molecules called chemokines on the cell surface to gain entry into cell. Patients who do not have these specific chemokines (CCR5) are more resistant HIV infection. The critical abnormality resulting from HIV infection is progressive decline in the number of CD4+T-lymhocytes. The CD4+T cell count serves as the major laboratory indicator of immune function in patients who have HIV infection. It is one of the key factors in deciding whether to initiate ART and prophylaxis for opportunistic infections and it is the strongest predictor of subsequent disease progression and survival [20]. In this study, HIV/AIDS patients on treatment had significantly higher values of CD4+T cells, leukocytes, lymphocytes and haemoglobin levels than HIV/AIDS patients not on treatment. This means that antiretroviral treatment suppresses HIV replication and restores immunity [27]. The haemoglobin level was significantly lower in HIV+ patients $(11.28 \pm 1.49 \mathrm{gm} / \mathrm{dl})$ than the reference values established for this population $(12.65 \pm 1.3$, $\mathrm{t}=27.5$, $\mathrm{df}=$ $461, \mathrm{p}=0.001$ ) which was statistically significant. Reasons for this could be insufficient dietary intake due poor appetite or anaemia resulting from chronic infections. Our findings also shows that HIV/AIDS patients were significantly malnourished as compared to the normal subjects for his population and TB patients. Malnutrition is normally associated with impaired immunity and it has been reported that malnourished individuals are at risk of acquiring tuberculosis [35]. This study found no significant difference between males and females with regards to nutritional status ( $\mathrm{p}>0.05$ ). In our study, total leucocyte (WBC) counts of HIV+ patients were found to be significantly $(\mathrm{p}<0.001)$ lower $(5.9 \pm 2.42) \times 10^{9} / \mathrm{l}$ as compared with HIV- control group $(6.92 \pm 3.12) \times$ $10 \%$. Leucocytopenia is known to increase the incidence of opportunistic infections in HIV patients. This decrease could have been due to soluble inhibitory substances produced by HIV infected cells noted to suppress cells production [37].

In multivariate analysis, immunohaematological markers (white blood cell count, packed cell volume and platelets) were found to be independently associated with HIV infection. The differences in the white blood cells count based to gender may be due to hormonal but the end results are often similar. The packed cell volume (PCV) incontrols show that females were more prone to blood loss, implying higher strain on their erythropoietic activities secondary toregulate menstrual [36]. The reduction in the number of circulatory cells is a common complication of HIV infection and in the course of the disease more than $70 \%$ of the patients develop anaemia that frequently required transfusion [37] [38]. The ESR value of HIV+ patients (102.0 $\pm 17.4 \mathrm{~mm} / \mathrm{hr})$ obtained in this study was significantly higher than control value $(10.0 \pm 8.5 \mathrm{~mm} / \mathrm{hr})$. This agrees with previous findings [42]. ESR is often raised in infections and inflammatory conditions. Increase in ESR could be attributed to production of acute phase proteins often observed in chronic infections and release of proteins by causative organism into the circulation. From this observation one may suggest that erythrocyte sedimentation rate could be used as sensitive index of plasma protein changes which result from inflammation or tissue damage. The number of HIV cases needing to be put on ART has been established in the present study. Moreover, nearly half of HIV-positive patients had a CD4 count less than or equal to 350 cells $/ \mathrm{mm}^{3}$. The percentage of individuals eligible for ART may therefore actually be higher and many of them may have AIDS-defining opportunistic infections that make them eligible for treatment. Nationally, however, of the 1.9 million Kenyans infected with HIV, about 42.9\% (245,000/570,000) of those needing ART are on ARVs. This means that universal Access to ART in Kenya is a big challenge [39].

\section{Limitations of the Study}

This study surveyed only sentinel sites mostly in high-population density areas of Mombasa and parts of its en- 
virons. Similar studies should be performed in other regions.

\section{Conclusion}

We conclude that the prevalence of HIV among suspected TB cases in the urban Kenyan setting is high and predominantly affects women. Lower CD4 lymphocytes count was found to be the only predicting factor for HIV. While significantly reduced $\mathrm{Hb}$ and PCV were common feature in HIV+ patients, significantly increased haemorheologic activity represented by raised ESR was also observed in these patients thus pre-disposing them to thrombosis and vascular complications. We suggest that much more effort needs to be directed to prevention of new HIV infections among the youth. The study also regards the utility of determination of CD4 cell level as a useful predictor of AIDS during monitoring of patients with HIV/AIDS infection in Kenyan conditions.

\section{Acknowledgements}

We thank the Medical Officers of Health, Medical Superintendents, District Leprosy and Tuberculosis Coordinators, Laboratory staff and clinical officers and nursing staff at Coast Provincial General Hospital, Portreitz, Tudor and Likoni District Hospitals, Mlaleo and Mikandani Health Centers who greatly assisted us with specimen and data collection for this study. We are also indebted to the Laboratory Technicians at Central Reference Laboratory, KEMRI who assisted in isolation of Mycobacterium tuberculosis through culturing. We wish to thank Technical University of Mombasa for partly funding this study. Most importantly, our sincere gratitude goes to the patients who consented to this study.

\section{Competing Interest}

Authors have declared that no competing interests exist.

\section{Authors' Contribution}

This work was carried out in collaboration between all others. Author SAY collected the data, did statistical analysis and drafted the manuscript. MFO and RRS initiated the study and made major contributions to the study design. All authors read and approved the final manuscript.

\section{References}

[1] Stover, J., Brown, T. and Marston, M. (2012) Updates to the Specrtrum/Estimation and Projection Package (EPP) Model to Estimate HIV Trends for Adults and Children. Sexually Transmitted Infections, 88, 11-16. http://dx.doi.org/10.1136/sextrans-2012-050640

[2] Aderaye, G. (2007) Pulmonary TB and Pneumocystis Jeroveci Pneumonia in HIV in HIV Infected Patients in Ethopia. http://diss.kib.ki.se/2007/978-91-7357-123-4/thesis

[3] WHO (2013) Global Tuberculosis Control, Surveillance, Planning and Financing: WHO Report, WHO/HTM/TB, World Health Organization, Geneva, 349.

[4] Nyamogoba, H., Mbuthia, G. and Obel, M. (2011) A High Rate of Human Immodeficiency Virus Infection among Suspected Tuberculosis Cases in Western Kenya. African Journal of Health Sciences, 19, 36-40.

[5] Delany, M.S., Bello, B., Kinross, P., et al. (2013) HIV Prevalence and Risk in Long-Distance Truck Drivers in South Africa: A National Cross-Sectional Survey. International Journal of STD \& AIDS, 25, 428-438. http://dx.doi.org/10.1177/0956462413512803

[6] United Nations \& AIDS (UNAIDS) (2013) Accelerating Action against AIDS in Africa. Geneva, Switzerland.

[7] National AIDS Control Council (NACC) (2013) Global Facts and Figures: The Global AIDS Epidemic.

[8] Agot, K.E., Vandor, S., Tracy, M., Obare, B.A., Bukusi, E.A., et al. (2010) Widow Inheritance and HIV Prevalence in Bondo District, Kenya: Baseline Results from Prospective Cohort Study. PLoS ONE, 5, e14028. http://dx.doi.org/10.1371/journal.pone.0014028

[9] National AIDS Control Council (NACC) and National AIDS and STD Control Programmme (2012) Estimates and Interim Projected HIV Prevalence and Incidence and Trends for 2008-2015.

[10] National AIDS Control Program, Ministry of Medical Services, Government of Kenya (2013) Scale up of Access to ART in Kenya. 
[11] National AIDS and STD Control Programme. Ministry of Medical Services, Government of Kenya (2013) Scale up of Access to ART in Kenya.

[12] Sanders, E.J., Grahamc, S.M., Okuku, H.S., Van der Elst, E.M., Muhari, A., Davies, A., Peshu, N., et al. (2007) HIV-1 Infection in High Risk Men Who Have Sex with Men in Mombasa, Kenya. AIDS, 21, 2513-2520.

http://dx.doi.org/10.1097/QAD.0b013e3282f2704a

[13] Jones, B., Young, S.M., Antoniskis, D., Davidson, P., Kramer, F. and Barnes, P. (1993) Relationship of the Manifestations of Tuberculosis to CD4 Cell Counts in Patient with Human Immunedefficiency Virus Infections. American Review of Respiratory Disease, 148, 1292-1297. http://dx.doi.org/10.1164/ajrccm/148.5.1292

[14] Miaini, M.K., Gilson, R.J.C., Chavada, N., Gill, S., Fakayo, A., Ross, E.J., Philips, A.N. and Weller, I.V.D. (1996) Reference Ranges and Sources of Variability of CD4 Counts in HIV-Seronegative Women and Men. Journal of Genitourinary Medicine, 72, 27-31. http://dx.doi.org/10.1136/sti.72.1.27

[15] Uppas, S., Verma, S., Dhot, P., et al. (2005) Normal Values of CD4 and CD8 Lymphoctes Subsets in Healthy Indian Adults and the Effects of Sex, Age Gender and Smoking. Cytometry Part B: Clinical Cytometry, 52, 32-36.

[16] Mientjes, G.H., Ameijden, E.J., Roos, M.T., Leeuw, N.A., Coutinho, R.A. and Miedema, F. (1992) Large Diurnal Variation in CD4 Cell Count and T-Cell Function among Drug Users: Implications for Clinical Practice and Epidemiological Studies. AIDS, 6, 1269-1272. http://dx.doi.org/10.1097/00002030-199211000-00005

[17] Shahabbuddin, S. (1995) Quatitative Differences in CD8+ Lymphocytes, CD4/CD8 Ratio, NK Cells and HLA-DR (+)-Activated T Cells of Racially Different Male Populations. Clinical Immunology and Immunopathology, 75, 168170. http://dx.doi.org/10.1006/clin.1995.1067

[18] Prins, M., Robertson, J.R., Brettle, R.P., Aguado, H., Broers, B., Boufassa, F., Goldberg, D.J., Zangerle, R., Coutinho, R.A. and van den Hoek, A. (1999) Do Gender Differences in CD4 Cell Counts Matter? AIDS, 13, 2361-2364. http://dx.doi.org/10.1097/00002030-199912030-00007

[19] Jannosy, G. and Golide, W. (2000) Affordable CD4 T-Cells Count on Single Platform Flow Cytometers. CD4 Gating. Brazil Journal of Haematology, 111, 1198-1208. http://dx.doi.org/10.1046/j.1365-2141.2000.02433.x

[20] Lawson, L., Yassin, M., Thatcher, T., et al. (2008) Clinical Presentation of Adults with Pulmonary Tuberculosis with and without HIV Infection in Nigeria. Scandinavian Journal of Infectious Diseases, 40, 30-35. http://dx.doi.org/10.1080/00365540701509899

[21] Cohen, B. and Trussel, J. (2006) Preventing and Mitigating AIDS in Sub-Saharan Africa: Research and Data Priorities for the Social Behavioural Sciences. The National Academy press, Washington DC.

[22] Trinity Biotech (2008) Uni-Gold ${ }^{\mathrm{TM}}$ HIV Insert.

[23] Abbot Murex, Murex Biotech Limited, the United Kingdom (2007) Murex HIV Ag/Ab Combination Insert.

[24] Daley, C., Small, P., Scheeter, G., School Link, G., McAdam, R., Jacobs, W. and Hopewell, P. (1992) An Outbreak of Tuberculosis with Accelerated Progression among Persons Infected with Human Immunodeficiency Virus-An Analysis Using Restriction-Fragment-Length Polymorphism. New England Journal of Medicine, 326, 231-235. http://dx.doi.org/10.1056/NEJM199201233260404

[25] Brenan, C.A., Bodelle, P., Coffey, R., et al. (2008). The Prevalence of Diverse HIV-1 Strains Was Stable in Cameroonian Blood Donors from 1996 to 2004. Journal of Acquired Immune Deficiency Syndromes, 49, 432-439. http://dx.doi.org/10.1097/qai.0b013e31818a6561

[26] Nyobi, B.M., Kristiansen, K.I., Bjune, G., Müller, F. and Holm-Hansen, C. (2008) Diversity of Human Immunodeficiency Type 1 Subtype in Kegera and Kilimanjaro Regions, Tanzania. AIDS Research and Human Retroviruses, 24, 761-769. http://dx.doi.org/10.1089/aid.2007.0311

[27] Zacharia, R., Fitzgerald, M., Massaquoi, M., Acabu, A., Chilomo, D., Salaniponi, F. and Harries, A.D. (2008) Does Antiretroviral Treatment Reduce Case Fatality among HIV-Positive Patients with Tuberculosis in Malawi? International Journal of Tuberculosis and Lung Disease, 11, 848-853.

[28] Jemikalajah, J. and Okogun, G. (2009) Health Point Prevalence of HIV and Pulmonary Tuberculosis among Patients in Various Parts of Delta State. Nigeria. Saudi Medical Journal, 30, 387-391.

[29] Matee, M., Mtei, L., Lounasvaara, T., Weiland-Alter, W., Waddell, R., Lyimo, J., Bkari, M., Pallangyo, K. and Von, C. (2008) Sputum Microscopy for Diagnosis of HIV-Associated Pulmonary Tuberculosis in Tanzania. BMC Public Health, 8, 68-72. http://dx.doi.org/10.1186/1471-2458-8-68

[30] Kalichman, S.C., Simbavi, L.C., Kaufman, M., Cain, D., Jooste, S., et al. (2007) Alcohol Use and Sexual Risks for HIV/AIDS in Sub-Saharan Africa: Systematic Review of Empirical Findings. Prevention Science, 8, 141-151. http://dx.doi.org/10.1007/s11121-006-0061-2

[31] Murill, C.S., Prevots, D.R., Miller, M.S., Linely, L.A., Royalty, J.E., Gwinn, M., et al. (2001) Incidence of HIV among Injection Drug Users Entering Drug Treatment Programs in Four US Cities. Journal of Urban Health, 78, 152-161. http://dx.doi.org/10.1093/jurban/78.1.152 
[32] Tarbasi, P., Mirasaeidi, M., Amiri, M., Mansouri, D., Masjedi, M., Velayati, A., et al. (2008) Clinical and Laboratory Profile of Patients with Tuberculosis/Co-Infection at a National Referral Centre: A Case Series. National Research Institute of Tuberculosis and Lung Diseases, Tehran.

[33] Tegbaruet, B., Messele, T., Hailu, E., Girma, M., Demissie, et al. (2001) Clinical Outcomes and Laboratory Results of Tuberculosis Patients with or without HIV Infection in Two Health Institutions in Addis Ababa Ethiopian Health and Nutrition Research Institute.

[34] Affussimet, C., Kesieme, E. and Abah, V. (2011) The Pattern of Presentation of Tuberculosis in HIV Seropositive Patients Seen at Benin City, Nigeria. Ambrose Alli University, Ekpoma.

[35] Nwachukwu, E. and Peter, G. (2010) Prevalence of Mycobacterium tuberculosis and Human Immmunodefiency Virus (HIV) Infections in Umuahia, Abia State, Nigeria. African Journal of Microbiology Research, 14, 1486-1490.

[36] Kusar, M., Koch, M., Mittrucker, W., Nouailles, G., Bonhagen, K., Kamradt, T. and Kauffman, H. (2007) Regulatory T Cells Prevent Efficient Clearance of Mycobacterium tuberculosis. Journal of Immunology, 178, 2661-2665. http://dx.doi.org/10.4049/jimmunol.178.5.2661

[37] Moore, D., Liechty, C., Palacious, E., et al. (2007) Prevalence, Incidence and Mortality Associated with Tuberculosis in HIV-Infected Patients Initiating Antiretroviral Therapy in Uganda. AIDS, 12, 713-719. http://dx.doi.org/10.1097/qad.0b013e328013f632

[38] Onubogu, C., Kunle-Ope, C., Onyejepu, N., Nwokoye, N.N., Raheem, et al. (2010) Prevalence of Tuberculosis and Human Immunodeficiency Virus (TB/HIV) Co-Infections amongst Patients with Bronchopulmonary Disorders in Lagos. African Journal of Microbiology Research, 7, 1904-1908.

[39] Ministry of Health, Kenya. (2013) National Leprosy and Tuberculosis Control Programme (NLTP). Annual Report.

[40] Ngowi, B.J., Mfinanga, S.G., Bruun, J.N and Morkve, O. (2009) Pulmonary Tuberculosis among People Living with HIVAIDS Attending Care and Treatment in Rural Northern Tanzania. BMC Public Health, 8, 341. http://dx.doi.org/10.1186/1471-2458-8-341

[41] Mmbanga, E.J, Hussein, A., Leyna, G.H., Mnyika, K.S., Sam, N.E., Klepp, K.I. et al. (2007) Prevalence and Risk factors for HIV-1 Infection in Rural Kilimanjaro Region of Tanzania: Implications for Prevention and Treatment. BMC Public Health, 7, 58. http://dx.doi.org/10.1186/1471-2458-7-58

[42] Ibeneme, E.O., Asuquo, A.E and Abia-Bassey, L.N. (2009) Prevalence of Pulmonary Tuberculosis and HIV Co-Infection among Prisoners in Calabar, Nigeria. Mary Slessor Journal of Medicine, 9, 198-203.

\section{List of Abbreviations}

TB-Tuberculosis,

PTB-Pulmonary Tuberculosis,

WHO_-World Health Organization,

MTB_Mycobacterium tuberculosis,

HIV_-Human Immunodeficiency Virus,

ART-Anti-Retroviral Treatment,

Hb-Haemoglobin,

PCV_-Packed Cell Volume,

WBC-White Blood Cell,

ERC-Erythrocyte Sedimentation Rate. 